\title{
DYNAMICS OF MICROBIAL CONTAMINATION IN A POULTRY HATCHERY
}

\author{
Iliqn Lazarov ${ }^{1}$, Georgi Zhelev²*, Mihni Lytzkanov², \\ Koycho Koev², Vladimir Petrov ${ }^{2}$ \\ ${ }^{1} \mathrm{PhD}$ student, Faculty of Veterinary Medicine, Trakia \\ University, 6000 Stara Zagora, Bulgaria \\ ${ }^{2}$ Department of Veterinary Microbiology, Infectious and Parasitic Diseases, \\ Faculty of Veterinary Medicine, Trakia University, 6000 Stara Zagora, Bulgaria
}

\section{Abstract}

The hatcheries may become contaminated with pathogenic bacteria which could spread in the hatchery through the air. That is why the implementation of an effective cleaning and disinfection program and the maintenance of good hygiene are extremely important for the normal course of production and for reducing the spread of infectious agents. In this study, data on the degree and dynamics of bacterial contamination in a poultry hatchery are presented. In the incubation sector, bacterial contamination on the surfaces was found to be low-level ranging from 0.25 to $4.43 \times 10^{1} \mathrm{CFU} /$ $\mathrm{cm}^{2}$ but in the air it was strongly influenced by the hatching. In the hatchery sector, bacterial contamination on the surface and in the air was high, with the highest values found on the egg shells $\left(1.77 \times 10^{6} \mathrm{CFU} / \mathrm{cm}^{2}\right)$, on the floor $\left(3.2 \times 10^{4} \mathrm{CFU} / \mathrm{cm}^{2}\right)$ and in the air $\left(1.77 \times 10^{5} \mathrm{CFU} / \mathrm{cm}^{3}\right)$ of hatcher cabinets during hatching. The results obtained show that the most important source of microbial contamination in the hatchery is the hatchery sector, especially during hatching, when highly contaminated materials as fluff, shells and dried secretions are released. In case of poor organization of working process, the bacteria could spread by air and contaminate the other sectors of the hatchery. The study confirms the importance of a different approach in the development of preventive measures, depending on the degree of risk in different zones in the hatchery, which is the basis for the effective management practice aimed at decreasing microbiological hazards in hatcheries.

Keywords: poultry, hatchery, microbial contamination, hygiene, risk

\footnotetext{
${ }^{1}$ Corresponding author: zhelev_vet@abv.bg
} 


\title{
DINAMIKA MIKROBIOLOŠKE KONTAMINACIJE U INKUBATORSKIM STANICAMA
}

\author{
Iliqn Lazarov' ${ }^{1}$, Georgi Zhelev² ${ }^{2}$, Mihni Lytzkanov², \\ Koycho Koev ${ }^{2}$, Vladimir Petrov ${ }^{2}$ \\ ${ }^{1}$ Student doktorskih studija, Fakultet veterinarske medicine, \\ Univerzitet Trakia, 6000 Stara Zagora, Bugarska \\ ${ }^{2}$ Departmant za veterinarsku mikrobiologiju, infektivne i parazitske bolesti, \\ Fakultet veterinarske medicine, Univerzitet Trakia, 6000 Stara Zagora, Bugarska
}

\section{Kratak sadržaj}

U inkubatorskim stanicama može doći do kontaminacije patogenim bakterijama koje se dalje šire putem vazduha. Iz tog razloga implementacija efikasnog programa čišćenja i dezinfekcije kao i pravilno održavanje higijene su od ključnog značaja za održavanje normalnog toka proizvodnje i ograničavanja širenja infektivnih agenasa. U ovoj studiji prezentivani su podaci o stepenu i dinamici bakterijske kontaminacije u inkubatorskoj stanici. U sektoru za inkubaciju ustanovljen je nizak nivo bakterijske kon-

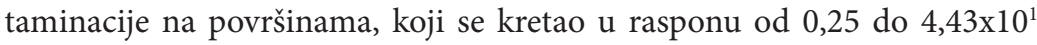
$\mathrm{CFU} / \mathrm{cm}^{2}$ ali je samo leženje imalo veliki uticaj na nivo kontaminacije $\mathrm{u}$ vazduhu. U sektoru za leženje pilića ustanovljen je visok nivo bakterijske kontaminacije na površinama i u vazduhu sa najvišim vrednostima izmerenim na ljusci jajeta $\left(1,77 \times 10^{6} \mathrm{CFU} / \mathrm{cm}^{2}\right)$, na podu $\left(3,2 \times 10^{4} \mathrm{CFU} / \mathrm{cm}^{2}\right)$ i u vazduhu $\left(1,77 \times 10^{5} \mathrm{CFU} / \mathrm{cm}^{3}\right)$ u inkubatorima tokom procesa leženja. Dobijeni rezultati ukazuju na to da je najvažniji izvor mikrobiološke kontaminacije u inkubatorskim stanicama sektor za leženje pilića, naročito tokom samog procesa leženja, kada dolazi do oslobađanja visoko kontaminiranih materijala kao što je paperje, ljuske i osušeni ekskreti. Ova studija je potvrdila značaj različitog pristupa u razvijanju preventivnih mera u zavisnosti od stepena rizika u različitim zonama inkubatorskih stanica, što predstavlja osnovu za efikasno upravljanje sa ciljem da se smanje mikrobiološki hazardi u inkubatorskim stanicama.

Ključne reči: živina, inkubatorska stanica, mikrobiološka kontaminacija, higijena, rizik 


\section{INTRODUCTION}

The hatcheries are animal husbandry facilities which may become contaminated with pathogenic microorganisms. Because of the constant air flow in hatchery there is a risk of disease transmission, especially during hatching process (Ayubi and Karadzhov, 1994a).

It is established that the extent of bacterial contamination in poultry hatcheries is one of the main factors influencing the egg hatching, the embryonic death and the vitality of newly hatched chicks (Mauldin, 2008; Qureshi, 2002). Thus, the implementation of an effective cleaning and disinfection program, and the maintenance of good hygiene is extremely important for the normal course of production and to reduce dissemination of pathogenic microorganisms (Ayubi and Karadzhov, 1994a; 1994b).

The aim of the present survey was to determine the level and the dynamics of bacterial contamination during the production process in a poultry hatchery. This would allow to identify the sources of bacterial contamination and to implement relevant preventive measures in different areas of the hatchery, which is an important prerequisite for the high efficiency of the disinfection program and application of the effective management systems in hatcheries.

\section{MATERIAL AND METHODS}

The study was carried out in a poultry hatchery located in South Bulgaria. A disinfection program was performed and it included fumigation of incoming eggs with formalin (53 $\mathrm{mL}$ formaldehyde, $35 \mathrm{~g}$ potassium permanganate per $1 \mathrm{~m}^{3}$ ), aerosol disinfection of incubator cabinets filled with eggs during the first day of incubation ( $30 \mathrm{~mL}$ formaldehyde per $1 \mathrm{~m}^{3}$ ), and daily prophylactic spray disinfection of the floor and walls in the hatcheries with aqueous disinfectant solution containing glutaraldehyde and quaternary ammonium compounds. The same disinfectant, in shape of foam is used for disinfection of the equipment as well as the empty hatchers and incubators after chickens have been removed.

The level and the dynamic of microbial contamination in each facility during the various technological stages were estimated by conventional techniques of microbiological testing. Thus, samples of different surfaces and the air were taken.

The samples of the surfaces were taken by microbiological swab method. A sterile cotton swab, soaked in sterile saline solution, was rubbed in a surface of $25 \mathrm{~cm}^{2}$ by using sterile metal template. The samples were put in tubes, con- 
taining $10 \mathrm{~mL}$ sterile saline solution and refrigerated during transportation to the laboratory. Sample homogenization and content extraction was performed by vigorous shaking in a vortex for 3 minutes, after which the tampons were removed from the tubes. Ten-fold dilutions (from $10^{-1}$ to $10^{-7}$ ) were prepared in sterile saline solution. For the quantification of the total number of mesophilic aerobic and facultative anaerobic microorganisms, aliquots of $0.1 \mathrm{~mL}$ from the primary dilution and the corresponding decimal dilutions were sowed in Tryptone Soya Agar (HiMedia, India). The samples were incubated at $37^{\circ} \mathrm{C}$ for $48 \mathrm{~h}$. The grown colonies were counted twice - on the 24th and 48th hour of the incubation, and final result was presented as the highest colony amount. The counting was performed by using a digital colony counter (Colony counter LA660, HiMedia, India).

The amount of microorganisms per $1 \mathrm{~cm}^{2}$ of the control surfaces was calculated depending on the number of grown colonies on the agar and the corresponding rate of dilution. For every control surface, 6 cotton swab samples were examined and the average results are presented.

The air samples were obtained by the passive sedimentation method. Petri dishes, containing Tryptone Soya Agar (HiMedia, India), with a diameter of $8.5 \mathrm{~cm}$ were used. The plates were arranged at different heights in the hatchery. They were opened for a certain period of time (from 2 to $10 \mathrm{~min}$.) pursuant to the expected microbial contamination. The samples were incubated at $37^{\circ}$ $\mathrm{C}$ for $48 \mathrm{~h}$. The grown colonies were counted twice-on the 24th and 48th hour of the incubation, and the highest number of bacteria cells was taken as a final result. Depending on the number of grown colonies on the agar and the exposure of the Petri dishes, a total bacterial count of $1 \mathrm{~m}^{3}$ was determined (Stryjakowska-Sekulska et al., 2007). For each studied zone, 6 Petri dishes were put on different levels, and the average results were taken.

The statistical data processing was performed using GraphPad software. The results were presented as the average amount of 6 tests \pm Standard deviation. Comparison of the results between two groups was performed by unpaired t-test. The differences were considered as statistically significant when $\mathrm{P}$ value was less than $0.05(\mathrm{P}<0.05)$.

\section{RESULTS}

The results of the microbiological examinations of the samples are presented in Table 1. 


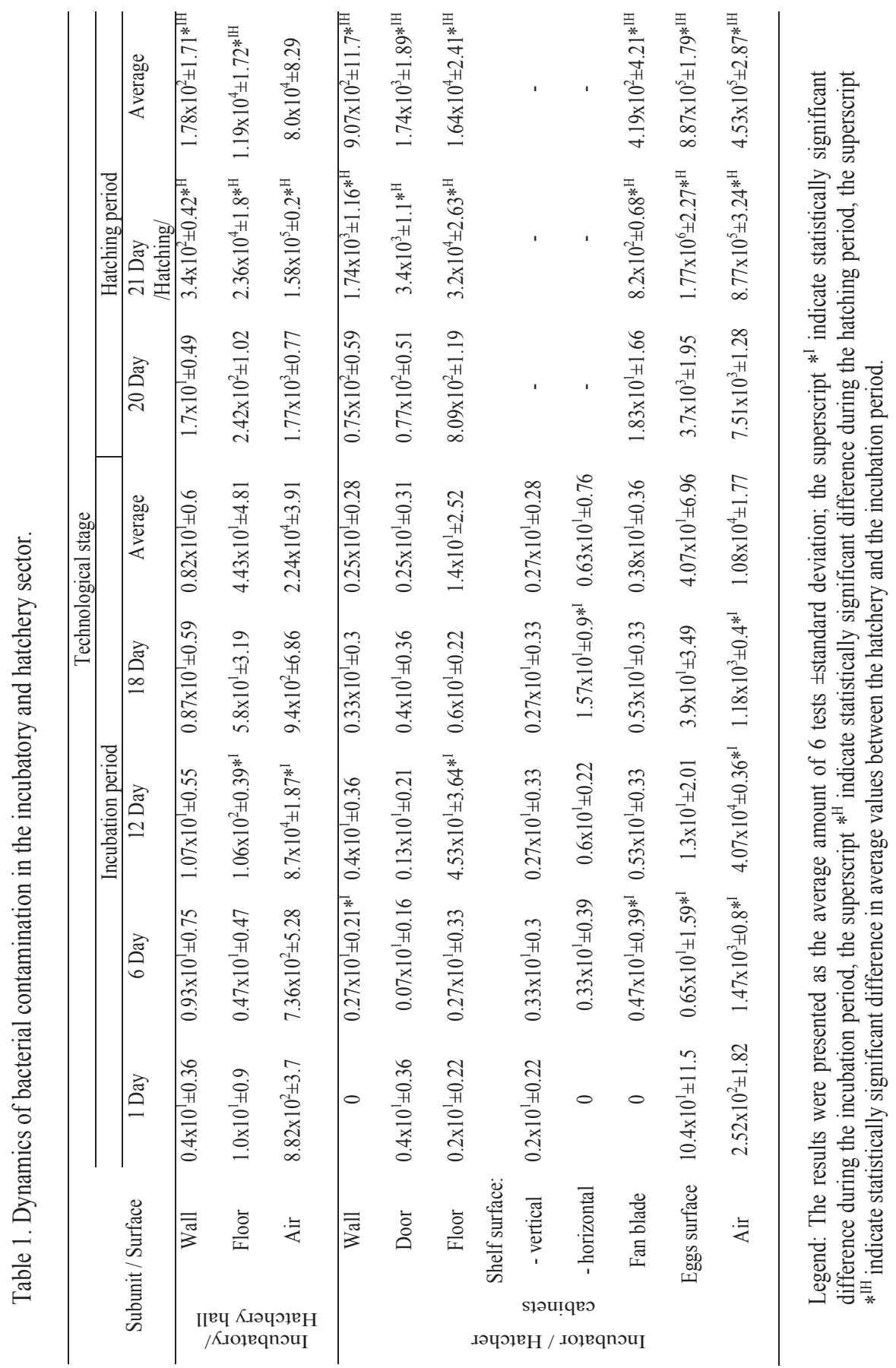




\section{DISCUSSION}

In this experiment, significant differences in the degree of microbial contamination between the incubator and the hatchery sector were established. In the incubator sector, the bacterial contamination of the eggs during the incubation period was relatively low $\left(4.07 \times 10^{1} \mathrm{CFU} / \mathrm{cm}^{2}\right)$ and no significant deviations were observed during the entire technological period. The residual microflora on the eggs when placed in incubators was low $-10.4 \times 10^{1} \mathrm{CFU} / \mathrm{cm}^{2}$. It was further reduced to $0.65 \times 10^{1} \mathrm{CFU} / \mathrm{cm}^{2}$ after the aerosol disinfection with formaldehyde on the incubators on the first day of incubation. In contrast, Ayubi et al. (1996) noticed significantly high rate of bacterial contamination on the egg shell during the first day of incubation $-1.6 \times 10^{2} \mathrm{CFU} / \mathrm{cm}^{2}$ in their study. Ours results show that the disinfection measures in the hatchery are highly effective. The high efficiency of the aerosol disinfection of hatching eggs with formalin is confirmed by Ayubi et al. (1994) in the laboratory tests and by Kim and Kim (2010) under field conditions.

The microbial contamination on the surfaces in the incubator sector was also relatively low (from $0.25 \times 10^{1}$ to $1.4 \times 10^{1} \mathrm{CFU} / \mathrm{cm}^{2}$ ) and no significant variations were observed during this technological stage. The bacterial contamination of the air in the incubator sector was considerably higher - from $1.08 \times 10^{4}$ in the incubators to $2.24 \times 10^{4} \mathrm{CFU} / \mathrm{cm}^{3}$ in the hall. The microbial contamination in the incubators was found to be significantly lower than that of the incubator hall. This particularity suggests that the source of microbial contamination in the incubator sector were not the eggs, therefore, it is most probably sought from outside. In connection with this, a dramatic increase of the bacterial air contamination in the incubation hall was found on the 12th day of incubation ranging from $7.36 \times 10^{2}$ to $8.7 \times 10^{4} \mathrm{CFU} / \mathrm{cm}^{3}$. According to us, this paradox can be explained by the fact that this period coincides with the end of the hatching process of the previous batch of eggs. During the preparation of the samples in the adjacent hatchery sector, the hatcher cabinets were emptied from the newly hatched chicks. Due to the lack of a separate buffer zone and a sanitary filter between the incubation and hatchery sector, there is an opportunity for easy transfer of contaminated air and materials between the two sectors.

In contrast to the incubator sector, significantly higher microbial contamination was found in the hatchery sector, and substantial variations were observed during the technological stage. It was established that microbial contamination increases dramatically during hatching. The highest increase levels were observed in microbial contamination on egg shells (478 times - from $3.7 \times 10^{3}$ to $\left.1.77 \times 10^{6} \mathrm{CFU} / \mathrm{cm}^{2}\right)$, in the air of hatchers $\left(116\right.$ times - from $7.51 \times 10^{3}$ 
to $8.77 \times 10^{5} \mathrm{CFU} / \mathrm{cm}^{3}$ ), on the floor of hatching hall (97 times - from $2.42 \times 10^{2}$ to $2.36 \times 10^{4} \mathrm{U} / \mathrm{cm}^{2}$ ), in the air of hatching hall ( 89 times - from $1.77 \times 10^{3}$ to $1.58 \times 10^{5} \mathrm{CFU} / \mathrm{cm}^{3}$ ), as well as the floor of hatchers (39 times - from $8.09 \times 10^{2}$ to $3.2 \times 10^{4} \mathrm{CFU} / \mathrm{cm}^{2}$ ).

The reports of other authors investigating microbial contamination in poultry hatcheries revealed that the high level of microbial contamination was determined in the hatchery sector and that microbial contamination increases drastically at the beginning of mass hatching (Ayubi and Karadzhov, 1994a; 1994b). The dramatic increase of microorganism population during hatching suggests that bacteria could penetrate inside fertilized eggs. It is well known that eggs can be contaminated with bacteria before lying, for example in hens infected with Salmonella, or secondarily after laying - during storage, transportation or incubation. Microorganisms that enter the egg surface may enter the egg through the pores of the shell (Lucore, 1994; Spitzer, 2015). During the incubation of the eggs, favourable conditions (appropriate temperature and humidity) are created to allow multiplication of the infiltrated microorganisms and their accumulation inside the eggs. Depending on the type of infiltrating microorganisms and their amount the result can be embryonic death or hatching of infected and / or diseased chicks, but in all cases there is a sharp and dramatic increase in microbial contamination during hatching (Ayubi and Karadzhov, 1994b; Kozhemyaka, 2010; Wilson, 1997).

The spread of the microorganisms from the hatchery sector to other parts of the facility can be done in different ways - via the air, equipment or staff. Qureshi (2002) puts the accent on the role of contaminated fluff released during hatching, which can easily be spread in the whole hatchery via the workers, the inventory or the air movements, leading to increase of the microbial contamination in all sectors in the hatchery.

Based on the obtained results we conclude that the most contaminated and high-risk area in the hatchery is the hatchery sector at the end of the hatchery process, which is the main source of microbial contamination of the entire hatchery. It is therefore necessary to establish a buffer zone and a sanitary filter between the hatchery and the incubator sector, restrict the passage of workers, hatchery equipment and tools to the incubation sector and also introduce disinfection program that takes into account the specificities of each area. 


\section{REFERENCES}

1. Ayubi N.M., Karadzhov S.: Disinfection of a hall for sexing and sorting of chickens by means of Desinfect B aerosol. Veterinarna Sbirka (BG), 102, 22-24, 1994a.

2. Ayubi N.M., Karadzhov S.: Investigations on the extent of egg surface bacterial contamination depending on post laying age. Veterinary science (BG), 28, 3, 82-86, 1994b.

3. Ayubi N. M., Karadzhov S., Gjurov B.: Disinfection of the egg shell surface with formaldehyde vapour. Veterinary science (BG), 28, 4, 68-72, 1994.

4. Ayubi N.M., Gyurov B., Karadzhov S., Naydenov V.: Investigations on bacterial contamination dynamics during incubation and hatching. Poultry Farming (BG), 6, 24-25, 1996.

5. Kim J.H., Kim K.S.: Hatchery hygiene evaluation by microbiological examination of hatchery samples. Poultry Science, 89, 7, 1389-1398, 2010.

6. Kozhemyaka N.: Antiepizootologic measures in hatcheries. Russ. Anim. Husbandry, 10, 17-21, 2010.

7. Lucore L.M.S. Thesis. NC State University, 1994.

8. Mauldin J.M.: Reducing contamination of hatching eggs, 2008. http:// en.engormix.com/MA-poultry-industry/articles/reducing-contamination-hatching-eggs-t1014/p0.htm (26 March 2018, date last accessed).

9. Qureshi A.: Hatchery sanitization and chick mortality. World Poultry, 18, 3, 2002.

10. Spitzer H.: An analysis of bacterial contamination of chicken eggs and antimicrobial resistance. Celebrating scholarship \& creativity day. 77, 2015. http://digitalcommons.csbsju.edu/elce_cscday/77 (26 March 2018, date last accessed).

11. 11. Stryjakowska-Sekulska M., Piotraszewska-Pajak A., Szyszka A., Nowicki M., Filipiak M.: Microbiological quality of indoor air in university rooms. Polish Journal of Environmental Studies, 16, 4, 623-632, 2007.

12. 12. Wilson H.R.: Hatching Egg Sanitation. Animal Science Department. Institute of Food and Agricultural Sciences, University of. Florida, PS22, 1997. 